Int. J. Odontostomat., 9(3):399-404, 2015.

\title{
Water and Physiological Saline to Prevent the Formation of P-Chloroaniline
}

\author{
Agua y Suero Fisiológico para Prevenir la Formación de Paracloroanilina
}

\author{
María José Riquelme*; Verónica Correa*; Pilar Araya*; Miguel Neira** \& Ismael Yévenes**
}

RIQUELME, M. J.; CORREA, V.; ARAYA, P.; NEIRA, M. \& YÉVENES, I. Water and physiological saline to prevent the formation of p-chloroaniline. Int. J. Odontostomat., 9(3):399-404, 2015.

ABSTRACT: This study determined if p-chloroaniline (PCA) can be minimized by using distilled water and physiological saline solution following sodium hypochlorite but before chlorhexidine. Hypochlorite 5\%, 0.5\%, 0.05\%, 0.005\% and 0.0005\% dissolved in $0.9 \% \mathrm{NaCl}$ and in distilled water were mixed with $2 \%$ chlorhexidine for the formation of PCA. The PCA was determined using UV-VISIBLE spectrometry, with spectral curve was determined the wavelength of maximum absorption of PCA. Formed PCA absorbance was measured between $0.025 \%, 0.02 \%, 0.015 \%, 0.01 \%, 0.005 \%$ and $0.0025 \%$ hypochlorite and $2 \%$ chlorhexidine. $2 \%$ chlorhexidine and hypochlorite with physiological saline form a white precipitate which prevents the measurement of PCA. Colored PCA is formed with $0.05 \%, 0.005 \%$ hypochlorite aqueous dilutions and $2 \%$ chlorhexidine. The Iwavelength of maximum absorption obtained was $470 \mathrm{~nm}$ and absorbance of PCA showed a linear decrease. $0.005 \% \mathrm{NaClO}$ produces the least amount of PCA. The best solvent to prevent the formation of PCA during the interaction of sodium hypochlorite with chlorhexidine is distilled water.

KEY WORDS: chlorhexidine; p-chloroaniline; distilled water; physiological saline solution; sodium hypochlorite.

\section{INTRODUCTION}

The objective in every endodontic treatment is to disinfect the whole root canal system before its obturation (Mohammadi, 2008). Studies have shown that conventional techniques of irrigation and implementation allow eliminating $90 \%$ of the bacterial colony. Ten percent of the remaining micro-organisms can proliferate between appointments reinfecting teeth at the same or at a greater extent than at the initial time of treatment (Siqueira, 2001). Therefore, it is necessary to use intracanal medication which increases treatment success rate from 68 to $95 \%$ according to Sjögren et al. (1997).

Many substances have been used for irrigation. However, and despite its permanence sodium hypochlorite has proven to be the chosen irrigator in modern practice due to its high tissue solution power, antibacterial and lubricant properties (Baumgartner \& Cuenin, 1992).

Intracanal medication is an adjuvant in endodontic therapy and it consists in the placing of a drug into root canals at each appointment. This adjuvant becomes more important every day in Endodontics since it is known that even with a complete biomechanical preparation bacteria remaining in the root canal system (Almyroudi et al., 2002). New substances have been tested, at the moment $2 \%$ chlorhexidine $(\mathrm{CHX})$ has proved to be the substance with better results, because at this concentration fungus Candida albicans (Basrani et al., 2004) and Enterococcus faecalis (Krithikadatta et al., 2007) can be eliminated, something that calcium hydroxide cannot do by itself. This was refuted by other authors, and accepted lately by Basrani et al. (2004) and reconfirmed by Krithikadatta et al. in 2007. The importance of CHX capacity to eliminate these two microorganisms is that there are always cases of rebel, refractory and persistent pathologies, and originating cases of endodontic therapy failure (Zerella et al., 2005).

The use of $2 \% \mathrm{CHX}$ is also grounded in its effect over bacteria which are commonly found in teeth with endodontic pathologies, since it acts over anaerobic

\footnotetext{
* Dental Science Department, Dental School, Universidad Andres Bello, Santiago, Chile.

"* Institute for Research in Dental Sciences, Dental School, Universidad de Chile, Santiago, Chile.
} 
or facultative (Kontakiotis et al., 2008), positive and negative Gram, i.e., it is a wide spectrum acting antiseptic, even if it presents a lower action over negative Gram than over positive Gram (Davis et al., 2007; Haapasalo et al., 2010).

One of the negative aspects of $\mathrm{CHX}$ is its inactivation in presence of organic matter, also present in other irrigants / drugs used in endodontic treatment and that it is unable to remove organic tissue or smear layer. But this characteristic is not important to acting as medication, since this disadvantage of $\mathrm{CHX}$ is overcome thanks to the irrigation with sodium hypochlorite and the posterior use of EDTA.

Other negative aspect is CHX's interactions as it is known, $\mathrm{CHX}$ is harmless to the organism (Manzur et al., 2007; Wang et al., 2007; Rossi-Fedele et al., 2013); however its interactions can be harmful. Lately, it has been studied that there is a chemical reaction when using $\mathrm{CHX}$ to medicate the root canal of a tooth treated with sodium hypochlorite. This chemical reaction produces an orange substance. In this reaction an aromatic amine called para-chloroaniline (PCA) is released which has been proved to be toxic (Bui et al., 2008; Rasimick et al., 2008).

PCA is toxic by inhalation, digestion or skin contact. It has the capacity to produce sensitization at skin contact too. It has also been observed that it is able to produce cancer (World Health Organization, 2003; State of New Jersey Department of Health, 2015). It is included in the list of the IARC (International Agency for Research on Cancer, 2015) for highly carcinogenic substances to humans, along with other mono-chloroanilines.

In 2007 Basrrani et al. (2007) carried out a study about $\mathrm{CHX}$ and sodium hypochlorite interaction. This aimed to give importance to the compound formed by them. In this study the immediate reaction between these substances is shown, even when using low concentrations of hypochlorite $(0.19 \%)$. As the hypochlorite concentrations rises, the precipitate increases in coloration and thickness, since this depends directly on sodium hypochlorite concentration (Bui et al.).

Inside the root canal, this precipitate affects the dentine's permeability, since at microscopic cuts dentinal tubules obliterated by PCA can be observed. This would imply sealing problems and, thus, it affects the treatment success (Prado et al., 2013). We do not known what concentration is required to cause damage in human tissues and whether this precipitate leaks out of the root canal system.

Diazotization, x-ray photon spectroscopy (XPS) and time-of-flight secondary-ion mass spectrometry (TOF-SIMS) have been used to characterize the $\mathrm{NaOCl} / \mathrm{CHX}$ precipitate with the conclusion that the substance formed is PCA (Basrani et al., 2007, 2009, 2010). Thomas \& Sem (2010) used $1 \mathrm{H}$ nuclear magnetic resonance (NMR) spectroscopy to determine the reaction between $\mathrm{NaOCl}$ and $\mathrm{CHX}$, they concluded that PCA was not produced at any measurable quantity and that further investigation is needed to determine the chemical composition of the brown precipitate.

Currently, it is generally believed once the irrigation with hypochlorite is finished that the number of residual bacteria is responsible for endodontic failures. It can be controlled by placing an interappointment medication within the prepared canal, $\mathrm{CHX}$ and Calcium hydroxide, are the most commonly used inter-appointment dressings to wash the root canal with abundant saline solution or distilled water to thus dilute the sodium hypochlorite to the extent that PCA would not be formed when getting together with the CHX (Rahimi et al., 2014).

Based on the data from previous studies, it has been recommended to exercise caution and use an alternative irrigating solution between $\mathrm{NaOCl}$ and $\mathrm{CHX}$ to prevent the formation of this precipitate (Basrani et al., 2007; Prado et al.). Hence, the purpose of this study was to evaluate two commonly used endodontic solutions such as distilled water and physiological saline and their effects on preventing the formation of PCA using UV-VISIBLE spectrometry.

\section{MATERIAL AND METHOD}

Sodium Hypochlorite solution (Sigma-Aldrich, St. Louis, MO., USA), 4-Chloroaniline (Sigma-Aldrich, St. Louis, MO., USA), Chlorhexidine digluconate solution $20 \%$ in $\mathrm{H}_{2} \mathrm{O}$ (Sigma-Aldrich, St. Louis, MO., USA), Sodium chloride p.a. (Sigma-Aldrich, St. Louis, MO., USA.). All chemical solutions were prepared by the chemistry laboratory at the faculty of dentistry based on the concentration requested. Solutions were then divided into two experimental groups of three tubes by 
dilution each and control of three tubes each. Tube type was identified and recorded appropriately.

Group 1. Hypochlorite dilution in $0.9 \%$ sodium chloride. The standard solution of $5 \%$ sodium hypochlorite was diluted successively with physiological serum solutions for $0.5 \%, 0.05 \%, 0.005 \%$ and $0.0005 \%$. Five hundred milliliters of each dilution was taken and added to Eppendorf tubes. The procedure was repeated three times to obtain 15 samples. To each sample $500 \mathrm{~mL}$ $2 \%$ chlorhexidine was added.

Group 2. Hypochlorite dilution in distilled water. The standard solution of $5 \%$ sodium hypochlorite was diluted successively with distilled water dilutions for $0.5 \%, 0.05 \%, 0.005 \%$ and $0.0005 \%$. Five hundred milliliters of each dilution was taken and added to Eppendorf tubes. The procedure was repeated three times to obtain 15 samples. To each sample $500 \mathrm{~mL}$ $2 \%$ chlorhexidine was added.

Group 3. Negative control. In three Eppendorf tubes with $500 \mathrm{~mL}$ of distilled water, $500 \mathrm{~mL}$ of $2 \%$ chlorhexidine was added.

Chemical measurement of the PCA compound. After the reaction was completed the solutions were prepared for analysis by UV-VISIBLE spectrometry. Spectrophotometric measurements were performed on spectrometer (Thermo SpectronicUnicam UV-530 UVVisible, Rochester, NY, USA) obtaining absorption spectrum. From the absorption spectrum of the value of max is obtained when the PCA compound has the highest absorbance. This is used when making qualitative and quantitative determinations of the PCA compound. Three samples per tube were taken and were deposited in 96-well plate. The samples were taken to the visible light spectrophotometer aiming to determine the maximum compound absorbance of PCA. Using the wavelength of maximum absorption all samples were read in the spectrophotometer to determine the absorbance. Once the absorbance values were obtained they were written on a graph to evaluate the curve and to determine when the PCA compound stops forming. The final concentration of sodium hypochlorite in each dilution is also determined.

\section{RESULTS AND DISCUSSION}

Group 1. Hypochlorite dilution in $0.9 \%$ sodium chloride. Contact between $\mathrm{NaOCl}, \mathrm{CHX}$ and sodium chloride produces a chemical reaction from which colored salt is formed. This colored salt is presented to the dilution $0.05 \%$ in $\mathrm{NaOCl}$, from $0.005 \%$ dilution the solution is colorless, from this concentration a white precipitate appears. This salt clouds the mix making absorbance measurement not unreliable, this is the reason absorbance is not measured.

Group 2. Hypochlorite dilution in distilled water. Compounding $\mathrm{p}$-chloroaniline is colored in the first 4 dilutions until the concentration of $0.005 \%$ in $\mathrm{NaOCl}$. With this solution absorption spectrum was performed to obtain a wavelength of maximum absorption of 470 $\mathrm{nm}$ (Fig. 1). This graph allows determining the work wavelength. It was determined that the average -in accordance to the curve- is between 450 and 500 wavelengths. The absorbance average to the wavelength is fixed at 470 .

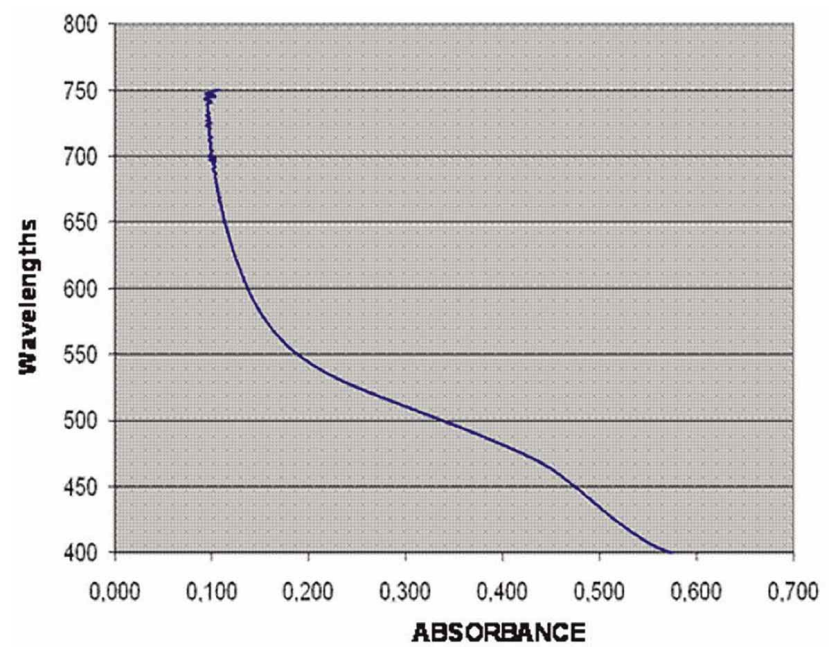

Fig. 1. Absorption spectrum of PCA, wavelengths $(\mathrm{nm})$ curve versus absorbance and determination of max.

From the solution of $0.05 \% \mathrm{NaOCl}, 2 \% \mathrm{CHX}$ and distilled water dilutions with final concentrations of $0.025 \%, 0.020 \%, 0.015 \%, 0.010 \%, 0.005 \%$ and $0.0025 \%$ expressed as $\mathrm{NaOCl}$ we proceeded to measure the absorbance at lambda max of each of the dilutions. Once these values were known the absorbance versus PCA concentration expressed as sodium hypochlorite graph was built (Fig. 2).

Group 3. Negative control. Chlorhexidine at wavelength of $470 \mathrm{~nm}$ has residual absorbance values do not affect the other measurements in the presence of $p$ chloroaniline. 


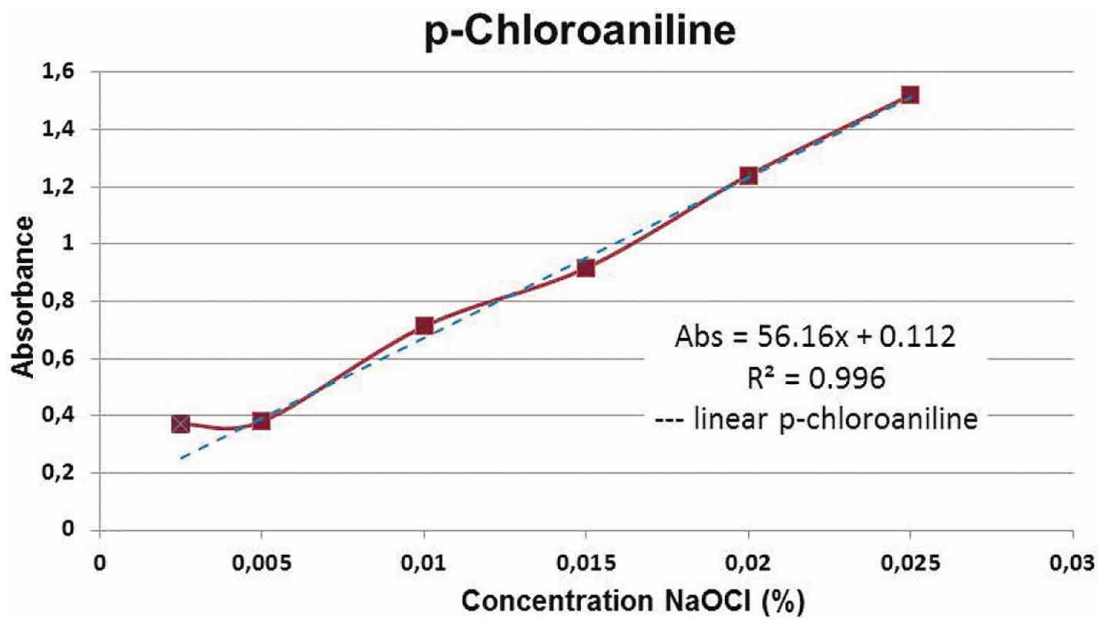

Fig. 2. Absorbance versus PCA concentration expressed as sodium hypochlorite. A linear decrease in absorbance was observed up to a concentration of $\mathrm{NaOCl}$ $0.005 \%$, with a minimum in the formation of PCA.

It is well known that the combination of hypochlorite and $\mathrm{CHX}$ produces a colored precipitate called PCA which is toxic for the organism. This also happens within the tooth. Likewise, it has been observed that residues of PCA are difficult to remove from the walls of the root canal, affecting dentine's permeability, which can create problems with the sealing and posterior prediction of success in treatment (Bui et al.).

These are the reasons why two ways to dilute sodium hypochlorite for non-formation of PCA when is mixed with $\mathrm{CHX}$ were tried out.

Contact between $5 \% \mathrm{NaOCl}$ and $2 \% \mathrm{CHX}$ formed PCA with a strong orange coloration. This happens because the compounds are not diluted as they are used in dental office. The coloration slightly decreases due to hypochlorite dilution in saline solution $(0.9 \%$ sodium chloride) and its concentration influences PCA formation directly. As the concentration of $\mathrm{NaOCl}$ decreases by dilution in physiological saline, the orange coloration decreases, a sign that PCA formation decreases but the formation of a white precipitate increases, showing an interaction between $\mathrm{CHX}$ and $0.9 \% \mathrm{NaCl}$. With this experiment we can tell that it is possible to decrease PCA formation with the dilution of hypochlorite in saline solution prior to the intracanal medication because no formation of colored precipitate is observed. However, the interaction between $\mathrm{CHX}$ and saline solution produces salt which without any doubt obliterates the dentinal tubules avoiding a proper contact between the sealing cement - wall and gutta-percha which decreases the possibilities of success in treatment. Saline solution diminishes PCA formation in bigger proportion than distilled water since it interacts with $\mathrm{CHX}$ forming salt and leaving less $\mathrm{CHX}$ to interact with sodium hypochlorite to produce PCA. The precipitates formed in the reaction of $\mathrm{CHX}$ with saline solution were associated with saltingout process, and lower solubility (Prado et al.).

Hypochlorite dissolves in distilled water and in the presence of $\mathrm{CHX}$ decreases strong orange coloration. The formation of PCA starts to linear decrease and in dilution of $0.005 \%$ in $\mathrm{NaOCl}$ practically no orange coloration is observed. No salt formation is observed since distilled water does not react with $\mathrm{CHX}$ or with sodium hypochlorite.

Measuring the absorbance determined that each of these dilutions was possible to find PCA and that this will always be produced while remnants of hypochlorite would exist in the mix. It is observed that the precipitate decreases considerably in color as sodium hypochlorite dilution increases, this is easily observed with unaided eye. PCA formation depends directly on sodium hypochlorite concentration, when shown on a graph the absorbance and link with PCA concentration expressed as sodium hypochlorite it is observed that starting from $0.005 \%$ concentration of sodium hypochlorite PCA formation starts to remain steady in the curve which indicates to us that from this dilution the minimum PCA can be obtained when contact with $2 \% \mathrm{CHX}$. It has been reported that Citric acid used as the intermittent irrigant had the least amount of PCA formation in the canal system. It can be hypothesized that positive results obtained with citric acid could be due to the partial release of the chlorine gas from the decomposition of $\mathrm{NaOCl}$ before the addition of $\mathrm{CHX}$. However, just as with distilled 
water, this did not completely prevent the formation of PCA (Mortenson et al., 2012).

According to our results, the formation of $p$ chloroaniline (PCA), measured by absorbance values, decreases linearly as the concentration of sodium hypochlorite diminishes. This relationship is governed by the equation: Absorbance $=56.16[\mathrm{NaOCl}]+0.112$, with a very good correlation coefficient $r=0.992$. This linearity (PCA formation and concentration of sodium hypochlorite) is maintained until the concentration of sodium hypochlorite $0.005 \%$, with this concentration becoming minimum value in the formation of PCA. If this leads to clinical practice, and assuming that a residue arbitrarily $5 \%$ sodium hypochlorite after drying with paper tips and aspiration the $50 \mu \mathrm{l}(0.05 \mathrm{~mL})$, the volume that should be washed (dilute) the duct to bring the concentration of hypochlorite to its minimum $(0.005 \%)$ is $50 \mathrm{~mL}$.

Subsequently, after irrigating a root canal with $5 \%$ sodium hypochlorite it must be dried with paper tips and aspiration if it is needed to medicate with $2 \% \mathrm{CHX}$ and if no PCA production is desired, compound which is toxic to the organism. The irrigation protocol used in the Faculty of Dentistry, Universidad of Chile, following the use of $10 \%$ EDTA, we proceeded to irrigate with saline solution with $3 \mathrm{~mL}$ three times. According to our results the serum of distilled water should be replaced, prior to use of $\mathrm{CHX}$ to $2 \%$, because water does not react with $\mathrm{CHX}$ as well as serum forming a precipitate with $2 \% \mathrm{CHX}$. Until the actual volume of sodium hypochlorite remaining $5 \%$ without knowing the root canals, the total volume of irrigation should keep 3 syringes of $3 \mathrm{~mL}$, with a total of $9 \mathrm{~mL}$. This situation is different for those (Mortenson et al.) protocols where after the use of EDTA 5\% sodium hypochlorite is reused, where the probability of finding residual hypochlorite posterior irrigation will be greatly increased and the greater will be the probability of forming PCA.

There are two studies that lead us to think it is the p-chloroaniline formed when reacting sodium hypochlorite and chlorhexidine. One notes that both XPS and TOF-SIMS showed the presence of $p$-chloroaniline in an amount directly related to the concentration of $\mathrm{NaOCl}$ used. Until this precipitate is studied further, its formation should be avoided by removing the $\mathrm{NaOCl}$ before placing $\mathrm{CHX}$ into the canal (Basrani et al., 2007). The other publication states: The TOF-SIMS results showed a peak at $127 \mathrm{mu}$, which is characteristic of 4chloroaniline. However, this could also be characteristic of other isomers of 4-chloroaniline such as 2- chloroaniline and 3-chloroaniline. The results showed an absence of other aniline derivatives in the precipitate. Only PCA was found (Basrani et al., 2010).

Another aspect originated in our results is that the product formed in interaction with $\mathrm{CHX}$ hypochlorite is feasible to measure and has a linear response when p-chloroaniline is used as standard spectrophotometric determinations.

\section{CONCLUSION}

Saline solution diminishes PCA formation since it interacts with $\mathrm{CHX}$, forming salt, leaving less $\mathrm{CHX}$ to interact with sodium hypochlorite to produce PCA. Distilled water diminishes PCA formation but it does not eliminate it completely since it only reduces sodium hypochlorite concentration. The best solvent of sodium hypochlorite to prevent the formation of PCA in contact with chlorhexidine is distilled water.

ACKNOWLEDGEMENTS. This study was supported by FIOUCH, CHILE, Grant \# 13-015.

RIQUELME, M. J.; CORREA, V.; ARAYA, P.; NEIRA, M. \& YÉVENES, I. Agua y suero fisiológico para prevenir la formación de Paracloroanilina. Int. J. Odontostomat., 9(3):399-404, 2015.

RESUMEN: Este estudio determinó si la p-cloroanilina (PCA) puede ser minimizada mediante el uso de agua destilada y solución salina fisiológica seguido de la aplicación de hipoclorito de sodio, previo a la aplicación de clorhexidina. Hipoclorito al $5 \%$, $0,5 \%, 0,05 \%, 0,005 \%$ y $0,0005 \%$ fue disuelto en $0,9 \%$ de $\mathrm{NaCl}$ y en agua destilada se mezcló con $2 \%$ de clorhexidina para la formación de PCA. EI PCA se determinó mediante espectrometría UV-Visible, y con curva espectral se determinó la longitud de onda máxima del PCA. La absorbancia del PCA formado se midió con $0,025 \%, 0,02 \%, 0,015 \%, 0,01 \%, 0,005 \%$ y $0,0025 \%$ de hipoclorito y $2 \%$ de clorhexidina. La combinación de $2 \%$ de clorhexidina e hipoclorito en solución salina fisiológica forman un precipitado blanco que impide la medición del PCA. El PCA coloreado es formado con $0,05 \%, 0,005 \%$ diluciones acuosas de hipoclorito y $2 \%$ de clorhexidina. La longitud de onda máxima obtenida fue de $470 \mathrm{~nm}$ y la absorbancia del PCA mostró una disminución lineal. $\mathrm{NaClO}$ al $0,005 \%$ produce menor cantidad de PCA. El mejor disolvente para evitar la formación de PCA durante la interacción de hipoclorito de sodio con clorhexidina es agua destilada.

PALABRAS CLAVE: clorhexidina, p-cloroanilina, paracloroanilina, agua destilada, solución salina fisiológica, hipoclorito de sodio. 


\section{REFERENCES}

Almyroudi, A.; Mackenzie, D.; McHugh, S. \& Saunders, W. P. The effectiveness of various disinfectants used as endodontic intracanal medications: an in vitro study. J. Endod., 28(3):1637, 2002.

Basrani, B.; Ghanem, A. \& Tjäderhane, L. Physical and chemical properties of chlorhexidine and calcium hydroxide-containing medications. J. Endod., 30(6):413-7, 2004.

Basrani, B. R.; Manek, S.; Sodhi, R. N.; Fillery, E. \& Manzur, A. Interaction between sodium hypochlorite and chlorhexidine gluconate. J. Endod., 33(8):966-9, 2007.

Basrani, B. R.; Manek, S. \& Fillery, E. Using diazotization to characterize the effect of heat or sodium hypochlorite on $2.0 \%$ chlorhexidine. J. Endod., 35(9):1296-9, 2009.

Basrani, B. R.; Manek, S.; Mathers, D.; Fillery, E. \& Sodhi, R. N. Determination of 4-chloroaniline and its derivatives formed in the interaction of sodium hypochlorite and chlorhexidine by using gas chromatography. J. Endod., 36(2):312-4, 2010.

Baumgartner, J. C. \& Cuenin, P. R. Efficacy of several concentrations of sodium hypochlorite for root canal irrigation. J. Endod., 18(12):605-12, 1992.

Bui, T. B.; Baumgartner, J. C. \& Mitchell, J. C. Evaluation of the interaction between sodium hypochlorite and chlorhexidine gluconate and its effect on root dentin. J. Endod., 34(2):181-5, 2008.

Davis, J. M.; Maki, J. \& Bahcall, J. K. An in vitro comparison of the antimicrobial effects of various endodontic medicaments on Enterococcus faecalis. J. Endod., 33(5):567-9, 2007.

Haapasalo, M.; Shen. Y.; Qian, W. \& Gao Y. Irrigation in endodontics. Dent. Clin. North Am., 54(2):291-312, 2010.

International Agency for Research on Cancer. IARC Monographs on the Evaluations of Carcinogenic Risks to Humans. Lyon, World Health Organization, 2015. Available from: http:// monographs.iarc.fr/ENG/Classification/

Kontakiotis, E. G.; Tsatsoulis, I. N.; Papanakou, S. I. \& Tzanetakis, G. N. Effect of $2 \%$ chlorhexidine gel mixed with calcium hydroxide as an intracanal medication on sealing ability of permanent root canal filling: a 6-month follow-up. J. Endod., 34(7):866-70, 2008.

Krithikadatta, J.; Indira, R. \& Dorothykalyani, A. L. Disinfection of dentinal tubules with $2 \%$ chlorhexidine, $2 \%$ metronidazole, bioactive glass when compared with calcium hydroxide as intracanal medicaments. J. Endod., 33(12):1473-6, 2007.

Manzur, A.; González, A. M.; Pozos. A.; Silva-Herzog, D. \& Friedman S. Bacterial quantification in teeth with apical periodontitis related to instrumentation and different intracanal medications: a randomized clinical trial. J. Endod., 33(2):114-8, 2007.

Mohammadi, Z. Sodium hypochlorite in endodontics: an update review. Int. Dent. J., 58(6):329-41, 2008.

Mortenson, D.; Sadilek, M.; Flake, N. M.; Paranjpe, A.; Heling, I.;
Johnson, J. D. \& Cohenca, N. The effect of using an alternative irrigant between sodium hypochlorite and chlorhexidine to prevent the formation of para-chloroaniline within the root canal system. Int. Endod. J., 45(9):878-82, 2012.

Prado, M.; Santos Júnior, H. M.; Rezende, C. M.; Pinto, A. C.; Faria, R. B.; Simão, R. A. \& Gomes, B. P. Interactions between irrigants commonly used in endodontic practice: a chemical analysis. J. Endod., 39(4):505-10, 2013.

Rahimi, S.; Janani, M.; Lotfi, M.; Shahi, S.; Aghbali, A.; Vahid Pakdel, M.; Salem Milani, A. \& Ghasemi, N. A review of antibacterial agents in endodontic treatment. Iran Endod. J., 9(3):161-8, 2014.

Rasimick, B. J.; Nekich, M.; Hladek, M. M.; Musikant; B. L. \& Deutsch, A. S. Interaction between chlorhexidine digluconate and EDTA. J. Endod., 34(12):1521-3, 2008.

Rossi-Fedele, G.; Dogramacı, E. J.; Steier, L. \& de Figueiredo, J. A. Interaction between chlorhexidine-impregnated gutta-percha points and several chlorine-containing endodontic irrigating solutions. Int. Endod. J., 46(7):675-80, 2013.

Siqueira, J. F. Jr. Aetiology of root canal treatment failure: why welltreated teeth can fail. Int. Endod. J., 34(1):1-10, 2001.

Sjögren, U.; Figdor, D.; Persson, S. \& Sundqvist, G. Influence of infection at the time of root filling on the outcome of endodontic treatment of teeth with apical periodontitis. Int. Endod. J., 31(2):148, 1998.

State of New Jersey Department of Health. Hazardous Substance Fact Sheet, 4-Chloroaniline. New Jersey, Department of Health, 2015. Available from: http://nj.gov/health/eoh/rtkweb/documents/fs/ 1250.pdf

Thomas, J. E. \& Sem, D. S. An in vitro spectroscopic analysis to determine whether para-chloroaniline is produced from mixing sodium hypochlorite and chlorhexidine. J. Endod., 36(2):315-7, 2010.

Wang, C. S.; Arnold, R. R.; Trope, M. \& Teixeira, F. B. Clinical efficiency of $2 \%$ chlorhexidine gel in reducing intracanal bacteria. J. Endod., 33(11):1283-9, 2007.

World Health Organization (WHO). Concise International Chemical Assessment Document 48. 4-Chloroaniline. Geneve, World Health Organization (WHO), 2003. Available from: http:// www.who.int/ipcs/publications/cicad/en/cicad48.pdf

Zerella, J. A.; Fouad, A. F. \& Spangberg, L. S. Effectiveness of a calcium hydroxide and chlorhexidine digluconate mixture as disinfectant during retreatment of failed endodontic cases. Oral Surg. Oral Med. Oral Pathol. Oral Radiol. Endod., 100(6):75661, 2005.

Correspondence to:

Ismael Yévenes

Institute for Research in Dental Sciences

Dental School - University of Chile

Sergio Livingstone Pohlhammer 943

Metropolitan Region,

Santiago - CHILE

Received: 15-04-2015

Accepted: 08-10-2015

Email: iyevenes@odontologia.uchile.cl 